\title{
Identification of the cancer/testis antigens AKAP3 and CTp11 by SEREX in hepatocellular carcinoma
}

\author{
MYUNG-HA SONG ${ }^{1}$, KYUNG-UN CHOI ${ }^{2}$, DONG-HOON SHIN $^{2}, \mathrm{CHANG} \mathrm{HUN} \mathrm{LEE}^{2}$ and SANG-YULL LEE ${ }^{1}$ \\ Departments of ${ }^{1}$ Biochemistry and ${ }^{2}$ Pathology, School of Medicine, Pusan National University, \\ Yangsan-si, Gyeongsangnam-do 626-770, Republic of Korea
}

Received May 16, 2012; Accepted August 2, 2012

DOI: $10.3892 /$ or.2012.2002

\begin{abstract}
Cancer/testis (CT) antigens are considered promising target molecules for immunotherapy. To efficiently identify potential CT antigens, a testis cDNA library was immunoscreened with sera from hepatocellular carcinoma (HCC) patients. We isolated 3 different antigens, AKAP3, CTp11, and UBQLN3. Although AKAP3 and CTp11 have been previously reported as CT antigens, this is the first time that these 2 antigens have been isolated from HCC patients by SEREX. Conventional RT-PCR analysis showed that AKAP3 was frequently present in HCC cell lines (5/7) and HCC tissues (5/10), and the gene was broadly expressed in several cancer types, including breast cancer cell lines (3/6), breast cancer tissues (6/9), colon cancer cell lines (3/10), colon cancer tissues $(5 / 6)$, ovary cancer cell lines $(6 / 8)$, ovary cancer tissues (11/16), lung cancer cell lines (4/7) and lung cancer tissues (6/13). By phage plaque analysis, anti-AKAP3 antibody was detected in sera from 15 of $27 \mathrm{HCC}$ patients and 8 of 27 healthy donors. These data suggest that AKAP3 may be useful for diagnosis and immunotherapy in HCC patients.
\end{abstract}

\section{Introduction}

Hepatocellular carcinoma (HCC) is the third leading cause of cancer mortality worldwide. This malignancy occurs more often in men than in women, with the highest incidence rates reported in East Asia (1). Surgery remains the most effective treatment for HCC. However, only $20 \%$ of HCC patients are suitable for surgery, and recurrence in resected patients is as high as $70 \%$. The overall 5-year survival for resected patients is $\leq 19 \%$ (2). Therefore, the development of new therapeutics to prevent recurrence is necessary. To protect against recurrence, tumor antigen-specific immunotherapy is an attractive strategy (3). T cell-based immunotherapies for HCC have

Correspondence to: Professor Sang-Yull Lee, Department of Biochemistry, School of Medicine, Pusan National University, Beomeo-ri, Mulgeum-eup, Yangsan-si, Gyeongsangnam-do 626-770, Republic of Korea

E-mail: sangyull@pusan.ac.kr

Key words: SEREX, CT antigen, hepatocellular carcinoma, AKAP3 used a few tumor-associated antigens (TAAs) and their epitopes, including AFP (4), GPC (5), NY-ESO-1 (6), SSX-2 (7), MAGE-A (8), and TERT (9). However, clinical data for only alpha-fetoprotein (AFP) have been reported $(10,11)$. A prerequisite for the successful development of $\mathrm{T}$ cell-based immunotherapeutic approaches is the identification and characterization of immune responses to TAAs. Many TAAs have been identified during the last 2 decades using various techniques. These include $\mathrm{T}$ cell epitope cloning, MHC peptide elution, differential gene expression analysis, and serologic expression cloning (SEREX) (12-15).

Among these methods, the serologic analysis of recombinant cDNA expression libraries (SEREX) has provided a powerful approach to identify immunogenic tumor antigens. To date, over 2,500 tumor antigens have been identified from a variety of tumors using SEREX. These antigens can be classified into several categories, including mutational antigens $(5,10)$, differentiation antigens $(10,14)$, overexpressed antigens $(15)$, and cancer/testis (CT) antigens $(16,17)$.

Cancer/testis (CT) antigens are immunogenic protein antigens with expression restricted to the testis and a wide range of human tumor types that elicit both humoral and cellular immune responses in cancer patients (17). They are considered ideal targets for vaccine-based immunotherapy, and to date, more than $100 \mathrm{CT}$ antigens, including MAGE, NY-ESO-1, GAGE, BAGE, LAGE, and SSX2, have been identified (18). CT antigens are divided between those that are encoded on the $\mathrm{X}$ chromosome (CT-X antigens) and those that are not (non-X CT antigens) (19). Many CT antigens show heterogeneous expression patterns within the same tumor tissue (20). Additional CT antigens are needed for the development of polyvalent cancer vaccines designed to overcome the limited frequency and heterogeneity of CT antigen expression. CT antigens identified by SEREX to date include MAGE-A (21), NY-ESO-1 (22), SSX2 (23), SCP1 (24), NY-SAR-35 (25), SLCO6A1 (26), and BCP-20 (27). In our study, we performed SEREX analysis to screen a testicular cDNA library with the aim of isolating CT antigens in the sera of HCC patients. We isolated 2 previously defined CT antigens, AKAP3 and CTp11 $(28,29)$.

\section{Materials and methods}

Human tissues, sera, and cell lines. Human tumor tissues and sera were obtained from the Department of Pathology and the 


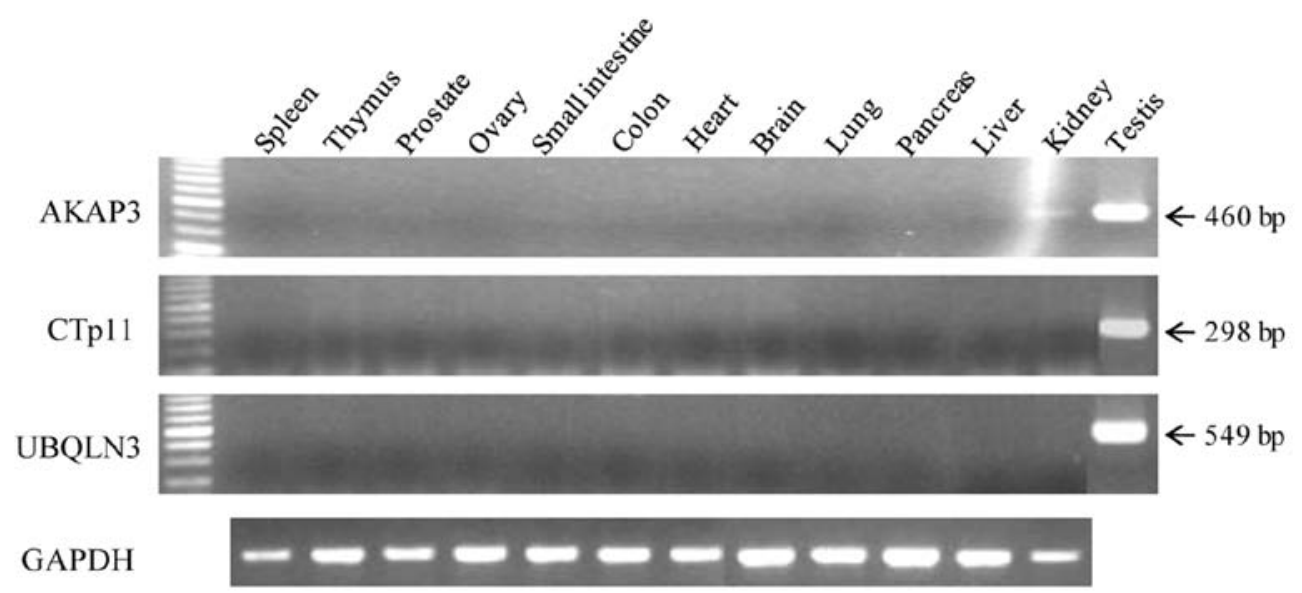

Figure 1. RT-PCR Analysis of AKAP3, CTp11, and UBQLN3 genes in normal tissues. The cDNA templates were normalized using GAPDH as shown in the bottom panel.

Korean National Biobank, Pusan National University Hospital after diagnosis and staging. The tissues were frozen in liquid nitrogen and stored at $-80^{\circ} \mathrm{C}$ until use. The human hepatoma cell lines SNU-354, SNU-398, SNU-423, SNU-449, SNU-475, and HepG2; human colon cancer cell lines SNU-C1, SNU-C2A, SNU-C4, and SNU-C5; and the human ovarian cancer cell lines SNU-8 and SNU-840 were obtained from the Korean Type Culture Collection (KTCC) and the American Type Culture Collection (ATCC). All cell lines were maintained in RPMI-1640 (Gibco-BRL Life Technologies Inc., Grand Island, NY, USA) medium supplemented with $10 \%$ fetal bovine serum, $2 \mathrm{mM}$ L-glutamine, $100 \mathrm{U} / \mathrm{ml}$ penicillin, and $100 \mu \mathrm{g} / \mathrm{ml}$ streptomycin.

Total RNA extraction from tissues and cell lines. Total RNA was isolated from human tissue samples and human tumor cell lines using the standard TRIzol reagent (Life Technologies, Gaithersburg, MD, USA) and RNA isolation kit (RNeasy Maxi kit, Qiagen) following manufacturer's instructions. Normal tissue total RNA was purchased from Clontech Laboratories, Inc. (Palo Alto, CA, USA) and Ambion, Inc. (Austin, TX, USA). Total RNA from several cancer cell lines used in this experiment was obtained from the Ludwig Institute for Cancer Research (LICR), New York Branch at the Memorial Sloan-Kettering Cancer Center.

Preparation of cDNA library and sera. Poly(A)+ RNA from normal testis was purchased from Clontech Laboratories, Inc. Five micrograms of mRNA was used to construct a cDNA library in the ZAP Express vector (Stratagene, La Jolla, CA, USA), following the manufacturer's instructions. The library contained $\sim 1,000,000$ recombinants, and was used for immunoscreening without prior amplification. Sera from 3 HCC patients were pooled and absorbed. The pooled serum was diluted 1:200 (final dilution, 1:600 for each serum) in Tris-buffered saline (TBS) containing 1\% BSA. The patients ages ranged from 74-79 years, all 3 were male, and all patients had stage I/II HCC. In addition to this pooled serum, all sera from HCC patients and healthy individuals in this study were diluted 1:200. To remove serum antibodies that react with Escherichia coli/bacteriophage-related antigens, sera were absorbed against $E$. coli/bacteriophage lysates as described by Lee et al (25).

Immunoscreening of cDNA library. Immunoscreening of the cDNA library was performed as previously described $(15,22)$. Briefly, E. coli XL1 blue MRF cells were transfected with the recombinant phages, plated at a density of approximately 5,000 $\mathrm{pfu} / 150-\mathrm{mm}$ plate (NZCYM-IPTG agar), incubated for $8 \mathrm{~h}$ at $37^{\circ} \mathrm{C}$, and then transferred to nitrocellulose filters (PROTRAN BA 85, $0.45 \mu \mathrm{m}$; Schleicher \& Schuell, Keene, NH, USA). Then the filters were incubated with a 1:200 dilution of patient sera, which had been preabsorbed to E. coli-phage lysate. The serum-reactive clones were detected with an AP-conjugated secondary antibody and visualized by incubation with 5-bromo-4-chloro-3-indolyl-phosphate/nitroblue tetrazolium (BCIP/NBT). After screening, the isolated positive clones were removed from the plate and preserved in suspension medium (SM) buffer with $25 \mu$ l of chloroform. Positive phages were mixed with a helper phage to co-infect XL-1 Blue MRF, and they were rescued into pBluescript phagemid forms by in vivo excision. The excised phagemids were transformed into the host bacteria (XLOLR) to multiply for plasmid extraction and stock creation. The size of the inserted cDNA was determined primarily by double restriction enzyme digestion with EcoRI and XhoI. The cDNA was commercially sequenced (Macrogen, Korea).

$R T-P C R$. The cDNA used as templates for RT-PCR reactions was prepared with $1 \mu \mathrm{g}$ of total RNA using the Superscript first strand synthesis kit (Invitrogen Life Technologies, Carlsbad, CA, USA). The PCR primers specific for AKAP3 and CTp11 were CTAACTTCGGCCTTCCCAGA (forward)/AGTGG GGTTGCCGATTACAG (reverse) and GGCGGGGTGAA GAGGAGCGT (forward)/ACACAGCCATCAGCTTCTC AAACTT (reverse), respectively. The cDNA templates were normalized based on the amplification of GAPDH. For PCR, a $20-\mu 1$ reaction mixture, including $2 \mu \mathrm{l}$ of cDNA, $0.2 \mathrm{mM}$ dNTPs, $1.5 \mathrm{mM} \mathrm{MgCl}, 0.25 \mu \mathrm{M}$ gene-specific forward and reverse primers, and $3 \mathrm{U}$ of Taq DNA polymerase (Solgent, Daejun, Korea), was preheated to $94^{\circ} \mathrm{C}$ for $5 \mathrm{~min}$, followed by 35 cycles of $94^{\circ} \mathrm{C}$ for $30 \mathrm{sec}, 60^{\circ} \mathrm{C}$ for $30 \mathrm{sec}$, and $72^{\circ} \mathrm{C}$ for 
Table I. HCC antigens by SEREX.

\begin{tabular}{|c|c|c|c|c|}
\hline Gene name & $\begin{array}{l}\text { Unigene } \\
\text { cluster }\end{array}$ & $\begin{array}{l}\text { Chromosome } \\
\text { location }\end{array}$ & $\begin{array}{l}\text { Number of } \\
\text { redundancies }\end{array}$ & $\begin{array}{c}\text { Previously } \\
\text { identified by SEREX }\end{array}$ \\
\hline AKAP3 & Hs.98397 & $12 \mathrm{p} 13.3$ & 2 & $\mathrm{Y}$ \\
\hline SPANXA2 & Hs.711784 & $\mathrm{Xq} 27.1$ & 1 & $\mathrm{~N}$ \\
\hline UBQLN3 & Hs.189184 & $11 \mathrm{p} 15$ & 1 & $\mathrm{~N}$ \\
\hline
\end{tabular}

UniGene cluster of isolated antigens (http://www.ncbi.nim.nih.gov/). Sequences were compared with those contained in the SEREX database of the Ludwig Institute for Cancer Research (http://ludwigsun5.unil.ch/CancerImmuno meDB/). Y and N indicate whether the antigen matched or did not match to an antigen in the SEREX database, respectively.

Table II. Summary of expression of AKAP3 and CTp11 mRNA.

\begin{tabular}{|c|c|c|c|c|}
\hline \multirow[b]{3}{*}{ Tumor type } & \multicolumn{2}{|c|}{ AKAP3 } & \multicolumn{2}{|c|}{ CTp11 } \\
\hline & Cell lines & Tissues & Cell lines & Tissues \\
\hline & \multicolumn{2}{|c|}{ (Positive/total) } & \multicolumn{2}{|c|}{ (Positive/total) } \\
\hline $\mathrm{HCC}$ & $6 / 7$ & $5 / 10$ & $5 / 8$ & $1 / 9$ \\
\hline Colon cancer & $3 / 10$ & $5 / 6$ & $1 / 10$ & $0 / 6$ \\
\hline Lung cancer & $4 / 7$ & $6 / 13$ & $4 / 10$ & $2 / 13$ \\
\hline Ovary cancer & $6 / 8$ & $11 / 16$ & $1 / 8$ & $0 / 15$ \\
\hline Breast cancer & $3 / 6$ & $6 / 9$ & $0 / 6$ & $0 / 9$ \\
\hline Melanoma & $1 / 8$ & ND & $0 / 9$ & ND \\
\hline Stomach cancer & ND & $8 / 9$ & ND & $0 / 9$ \\
\hline Small cell lung cancer & $0 / 5$ & ND & $0 / 5$ & ND \\
\hline Renal cell cancer & $2 / 2$ & ND & $0 / 2$ & ND \\
\hline Prostate cancer & $0 / 3$ & ND & $0 / 3$ & ND \\
\hline Leukemia & $2 / 3$ & ND & $0 / 3$ & ND \\
\hline Sarcoma & $2 / 3$ & ND & $2 / 3$ & ND \\
\hline Glioma & $1 / 2$ & ND & $0 / 2$ & ND \\
\hline
\end{tabular}

$\mathrm{ND}$, not determined.

$1 \mathrm{~min}$, with a final elongation step of $72^{\circ} \mathrm{C}$ for $5 \mathrm{~min}$. Amplified PCR products were analyzed on $1.5 \%$ agarose gels stained with ethidium bromide.

Phage plaque assay. To determine the immunoreactivity of the isolated clones, a phage plaque assay was performed as described previously (16). Briefly, phage from a positive clone were mixed with -ZAP clone without an insert as an internal negative control at a ratio $1: 1$, and then transfected into $E$. coli. Plaques were blotted onto nitrocellulose membranes and washed. Next, they were incubated with sera at $4^{\circ} \mathrm{C}$ for $16 \mathrm{~h}$. The spots were determined to be positive only if the tested clones were clearly distinguishable from the negative phage.

\section{Results}

Identification of HCC antigens by SEREX. A testis cDNA expression library of $\sim 2 \times 10^{5}$ clones was immunoscreened with pooled sera from HCC patients. Three clones representing 4 genes were isolated, and the antigens were AKAP3, CTp11, and UBQLN3. These 3 genes are associated with testis specific expression in the UniGene database. Comparison of the cDNA sequences encoding the antigens to those deposited in cancer immunome database showed that AKAP3 had been previously identified as NY-TLU-37 in lung cancer patients (26), while CTp11 and UBQLN3 had not been previously reported (Table I).

$m R N A$ expression in normal tissues, tumors, and cancer cell lines. To investigate the restricted expression of the mRNAs of the 3 genes in normal adult tissues, we performed conventional RT-PCR. As shown in Fig. 1, AKAP3 was strongly expressed in testis, but was weakly expressed in brain and kidney. In addition, expression of CTp11 and UBQLN3 mRNAs was restricted to the testis. The AKAP3 gene was expressed broadly and frequently in various cancer cell lines and cancer tissues, including HCC (6/7 and 5/10), colon cancer (3/10 and 5/6), lung cancer (4/7 and $6 / 13)$, ovarian cancer $(6 / 8$ and $11 / 16)$, and breast cancer $(3 / 6$ and 6/9), respectively (Fig. 2). In addition, AKAP3 mRNA was detected in melanoma cancer cell lines $(1 / 8)$, renal cancer 


\section{A Cancer cell lines}

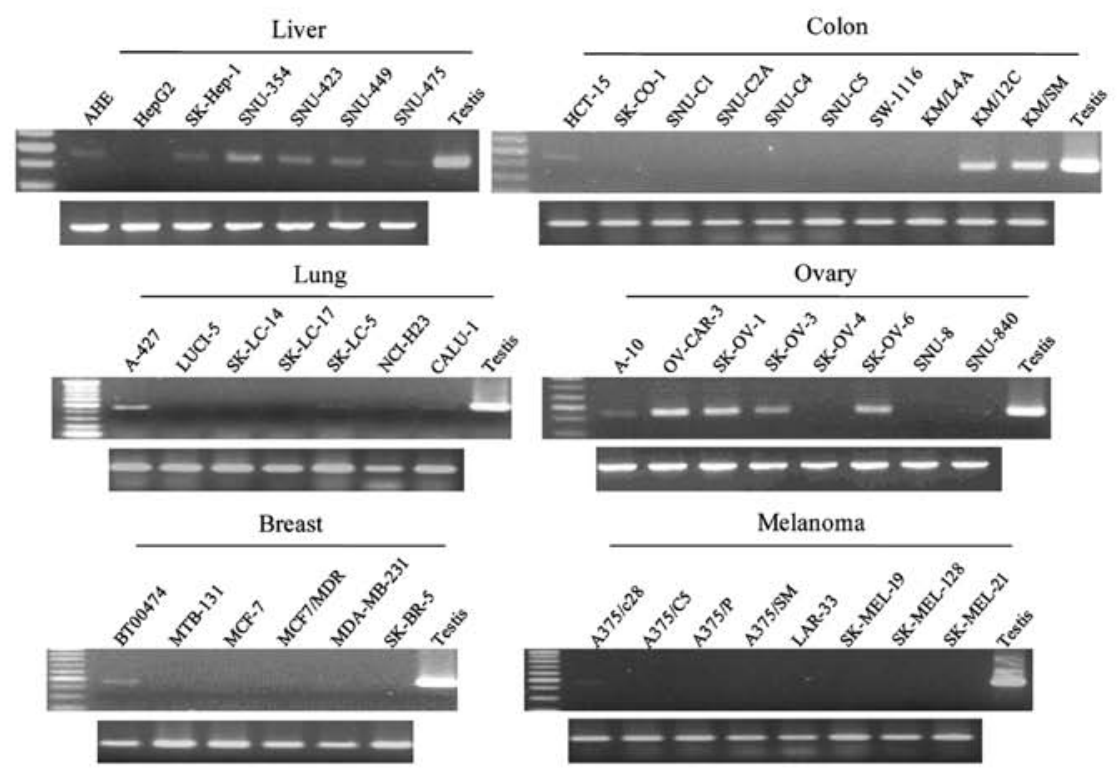

B Cancer tissues

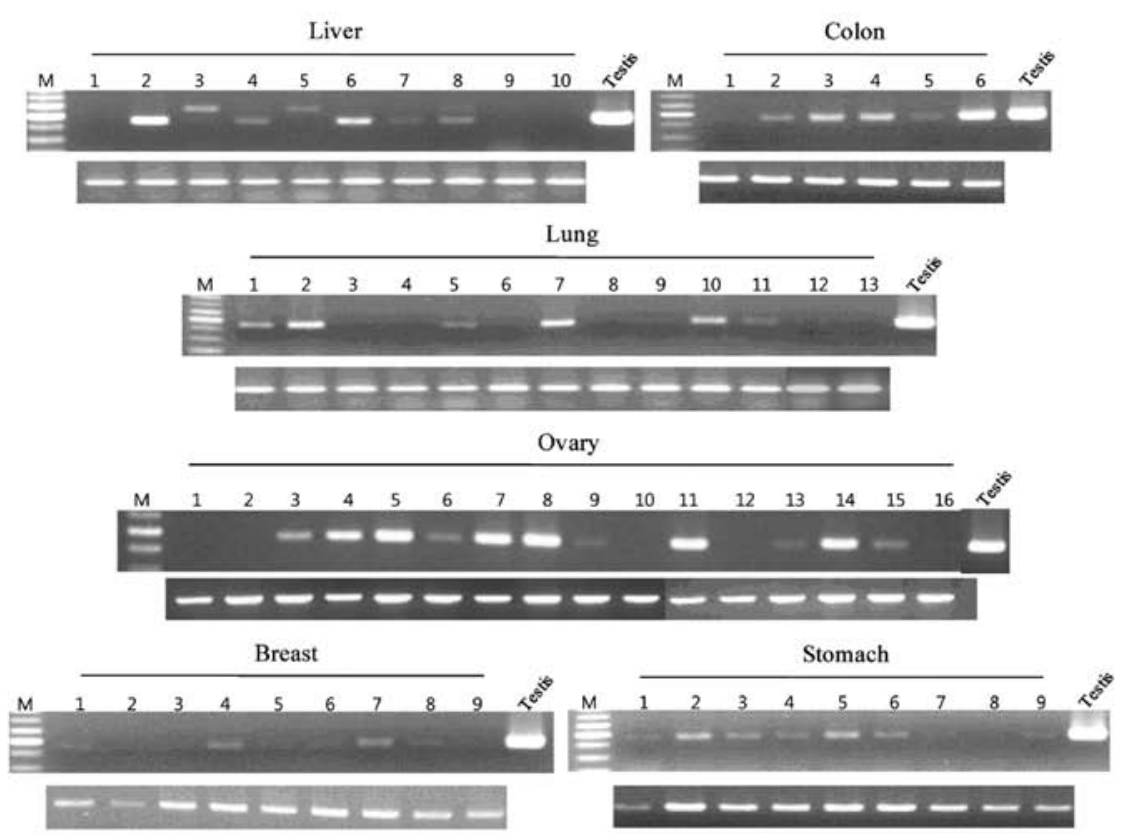

Figure 2. RT-PCR analysis of AKAP3 mRNA in cancer cell lines (A) and cancer tissues (B). The cDNA templates were normalized using GAPDH as shown in the bottom panel.

cell lines (2/2), leukemia cancer cell lines $(2 / 3)$, sarcoma cell lines $(2 / 3)$, and a glioma cell line $(1 / 2)$, but it was not detected in prostate cancer cell lines and small cell lung cancer cell lines (Table II). In addition, CTp11 was expressed in HCC cell lines and cancer tissues (5/8 and 1/9, respectively) and lung cancer cell lines and cancer tissues (4/10 and 2/13, respectively) (Fig. 3). However, CTp11 was either not expressed or infrequently expressed in various tumors and cancer cell lines, including breast cancer, colon cancer, and ovary cancer (Table II). These results indicate that AKAP3 is a CT antigen that is frequently expressed in a variety of cancers, including HCC.
Seroreactivity of the isolated antigens. To determine whether immune recognition of AKAP3, CTp11, and UBQLN3 proteins was cancer-related, allogeneic sera samples obtained from 27 normal blood donors and 27 patients with HCC were tested for reactivity by phage plaque assay. A representative phage plaque assay from the sera of HCC patients is shown in Fig. 4. Fifteen of 27 (63\%) sera samples from HCC patients and $8 / 27(30 \%)$ samples from normal patients were reactive against AKAP3. In contrast, 1 of $27 \mathrm{HCC}$ cancer sera samples reacted with CTp11 and UBQLN3, while none with sera samples from normal individuals reacted with $\mathrm{CTp} 11$ 
A Cancer cell lines

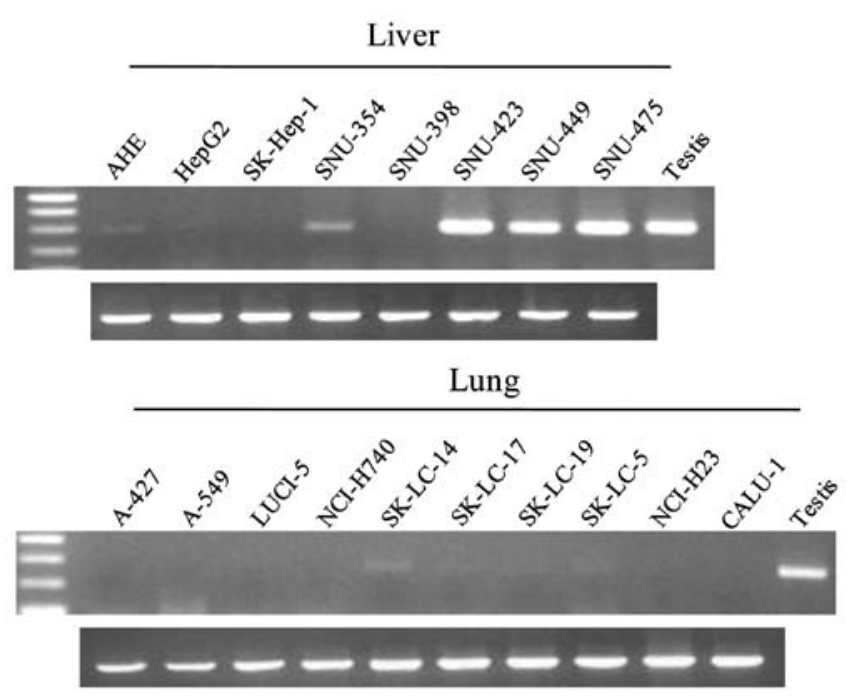

B Cancer tissues

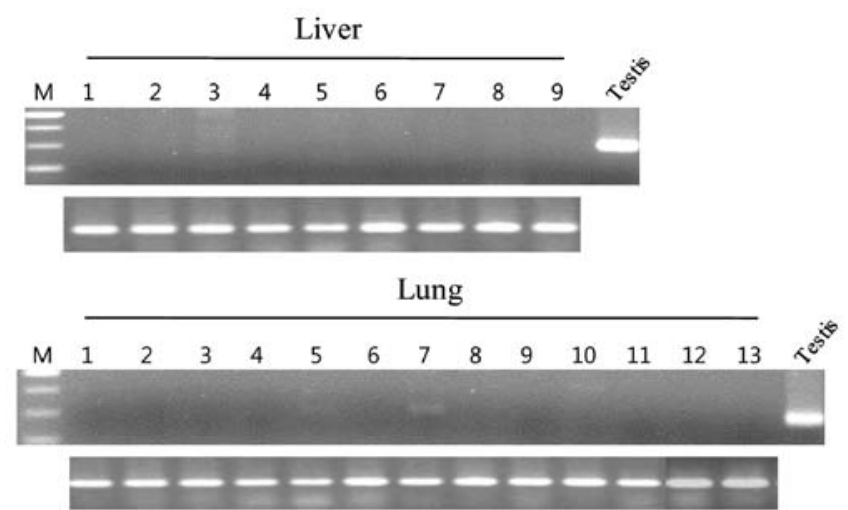

Figure 3. The mRNA expression of CTp11 in HCC and lung cancer cell lines (A) and tissues (B). The cDNA templates were normalized using GAPDH as shown in the bottom panel.

and UBQLN3. Although $8 / 27$ heath donors were positive for AKAP3 reactivity, $63 \%$ recognition by sera from $\mathrm{HCC}$ patients indicates that it may be an immunogenic tumor antigen.

\section{Discussion}

To identify additional immunoreactive antigens in HCC, a SEREX analysis was performed using a testis cDNA library and sera from HCC patients. Three distinct antigens were isolated, AKAP3, CTp11, and UBQLN3. UBQLN3 encodes an ubiquitin-like protein specifically expressed in the testis that has been proposed to regulate cell cycle progression during spermatogenesis (30). Conventional RT-PCR demonstrated strong UBQLN3 mRNA expression in testis; however, transcripts encoding UBQLN3 were not detected in cancer cell lines and tumor tissues (data not shown).

CTp11 was previously reported as a CT antigen isolated from a melanoma cell line by differential display (29). The gene encodes an 11-kDa protein and is located on chromo-
Negative

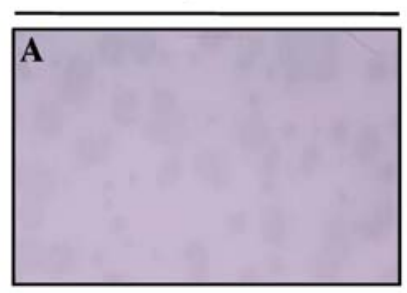

B

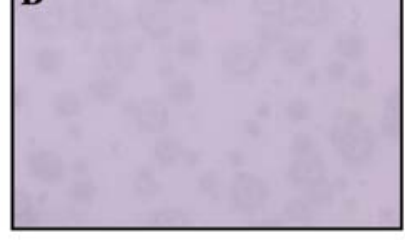

Positive

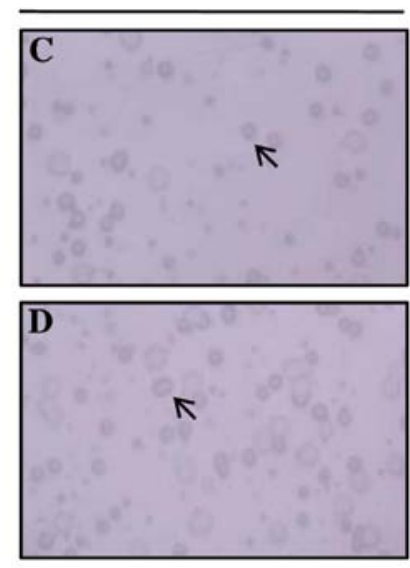

Figure 4. Representative phage plaque assay for AKAP3 from the sera of HCC patients. Seroreactivity of HCC patients for AKAP 3 was tested by phage plaque assay. $\lambda Z A P$ phages without insert are mixed with AKAP3 clones and serve as internal negative controls. The mixtures were transfected into E. coli. Plaques were blotted onto nitrocellulose membranes and incubated with sera of HCC patients (1:200 dilution). The spots were evaluated as positive (C and D) if AKAP3-encoding clones were clearly distinguishable from the control phage and was evaluated as negative (A and B) if the clone was not. Arrows indicated positive clones.

some Xq26.3-Xq27.1. CTp11 mRNA was expressed in $25-30 \%$ of the melanoma and bladder carcinoma cell lines tested, while only 2 of the 29 other tumor cell lines were positive. Recent studies reported a high frequency of CTp11 expression in $56.2 \%$ of HCC tissues and $31.1 \%$ of PBMC from HCC patients (31). In our study, CTp1 1 was expressed in $62 \%$ of HCC cell lines and $11 \%$ of HCC tissues. Although the frequency of CTp11 expression in our study differed from the previous results, we suggest the possibility of $\mathrm{CTp} 11$ antigen as a new potential candidate for HCC immunotherapy that will need to be further analyzed.

In addition, AKAP3 was previously reported as a CT antigen (28). A previous study showed that AKAP3 was a sperm protein, and that the mRNA was only expressed in the testis (32). This gene encodes a member of the A-kinase anchor proteins (AKAPs), and is only expressed in testis. The protein is localized to the ribs of the fibrous sheath in the principal piece of the sperm tail. It may function as a regulator of both motility- and head-associated functions, such as capacitation and the acrosome reaction (33). Two groups previously showed high AKAP3 mRNA expression in ovarian cancer, and expression was correlated to the histological grade and clinical stage of the tumors $(28,34)$. These previous reports showed AKAP3 mRNA expression in 58 and $28 \%$ of ovarian cancer specimens.

We demonstrated similar findings; high AKAP3 mRNA expression was observed in ovarian tumors (69\%) and ovarian cancer cell lines (75\%), suggesting that AKAP3 is a new independent prognostic factor for ovarian cancer patients. AKAP3 mRNA was broadly and frequently expressed in various tumors and cancer cell lines, including HCC (Fig. 2, Table II). In our study, AKAP3 was isolated for the first time from HCC patients by SEREX, was highly expressed in HCC tumors (5/10) and HCC cell lines (6/7), 
and anti-AKAP3 antibody was detected in 15 of 27 HCC sera samples by phage plaque analysis. These findings suggested that AKAP3 is a favorable molecular marker for prognosis and diagnosis in HCC patients. To address this possibility, we are examining AKAP3 mRNA expression in additional sera samples from HCC patients and investigating whether expression is correlated with the histological grade and clinical stage of tumors.

The correlation between AKAP3 mRNA expression and anti AKAP3 IgG was not evaluated due to a lack of paired samples; therefore, this should be investigated in a future study. Nonetheless, AKAP3 recognition by sera from HCC patients and healthy individuals indicates that AKAP3 is an immunogenic tumor antigen in HCC patients.

In conclusion, we reported for the first time the isolation of AKAP3 and CTp11 CT antigens from HCC patient sera by SEREX. We demonstrated high AKAP3 mRNA expression and high seroreactivity, which may have a favorable impact on diagnosis and immunotherapy of HCC patients.

\section{Acknowledgements}

The study was supported by a grant from Pusan National University (2011-2012).

\section{References}

1. Schutte K, Bornschein J and Malfertheiner P: Hepatocellular carcinoma - epidemiological trends and risk factors. Dig Dis 27: 80-92, 2009.

2. Butterfield LH: Recent advances in immunotherapy for hepatocellular cancer. Swiss Med Wkly 137: 83-90, 2007.

3. Breous E and Thimme R: Potential of immunotherapy for hepatocellular carcinoma. J Hepatol 54: 830-834, 2011.

4. Liu Y, Daley S, Evdokimova VN, Zdobinski DD, Potter DM and Butterfield LH: Hierarchy of alpha fetoprotein (AFP)-specific $\mathrm{T}$ cell responses in subjects with AFP-positive hepatocellular cancer. J Immunol 177: 712-721, 2006.

5. Komori H, Nakatsura T, Senju S, Yoshitake Y, Motomura Y, Ikuta Y, Fukuma D, Yokomine K, Harao M, Beppu T, et al: Identification of HLA-A2- or HLA-A24-restricted CTL epitopes possibly useful for glypican-3-specific immunotherapy of hepatocellular carcinoma. Clin Cancer Res 12: 2689-2697, 2006.

6. Gehring AJ, Ho ZZ, Tan AT, Aung MO, Lee KH, Tan KC, Lim SG and Bertoletti A: Profile of tumor antigen-specific CD8 $\mathrm{T}$ cells in patients with hepatitis B virus-related hepatocellular carcinoma. Gastroenterology 137: 682-690, 2009.

7. Bricard G, Bouzourene H, Martinet O, Rimoldi D, Halkic N, Gillet M, Chaubert P, Macdonald HR, Romero P, Cerottini JC and Speiser DE: Naturally acquired MAGE-A10- and SSX-2specific $\mathrm{CD}^{+} \mathrm{T}$ cell responses in patients with hepatocellular carcinoma. J Immunol 174: 1709-1716, 2005.

8. Zerbini A, Pilli M, Soliani P, Ziegler S, Pelosi G, Orlandini A, Cavallo C, Uggeri J, Scandroglio R, Crafa P, et al: Ex vivo characterization of tumor-derived melanoma antigen encoding gene-specific $\mathrm{CD}^{+}$cells in patients with hepatocellular carcinoma. J Hepatol 40: 102-109, 2004.

9. Mizukoshi E, Nakamoto Y, Marukawa Y, Arai K, Yamashita T, Tsuji H, Kuzushima K, Takiguchi M and Kaneko S: Cytotoxic $\mathrm{T}$ cell responses to human telomerase reverse transcriptase in patients with hepatocellular carcinoma. Hepatology 43: 1284-1294, 2006.

10. Butterfield LH, Ribas A, Dissette VB, Lee Y, Yang JQ, De la Rocha P, Duran SD, Hernandez J, Seja E, Potter DM, et al: A phase I/II trial testing immunization of hepatocellular carcinoma patients with dendritic cells pulsed with four alpha-fetoprotein peptides. Clin Cancer Res 12: 2817-2825, 2006.
11. Thimme R, Neagu M, Boettler T, Neumann-Haefelin C, Kersting N, Geissler M, Makowiec F, Obermaier R, Hopt UT, Blum HE and Spangenberg HC: Comprehensive analysis of the alpha-fetoprotein-specific $\mathrm{CD} 8^{+} \mathrm{T}$ cell responses in patients with hepatocellular carcinoma. Hepatology 48: 1821-1833, 2008.

12. Gaugler B, Van den Eynde B, van der Bruggen P, Romero P, Gaforio JJ, De Plaen E, Lethe B, Brasseur F and Boon T: Human gene MAGE-3 codes for an antigen recognized on a melanoma by autologous cytolytic T lymphocytes. J Exp Med 179: 921-930, 1994.

13. van der Bruggen $\mathrm{P}$, Traversari $\mathrm{C}$, Chomez $\mathrm{P}$, Lurquin $\mathrm{C}$, De Plaen E, Van den Eynde B, Knuth A and Boon T: A gene encoding an antigen recognized by cytolytic $\mathrm{T}$ lymphocytes on a human melanoma. Science 254: 1643-1647, 1991.

14. Pascolo S, Schirle M, Guckel B, Dumrese T, Stumm S, Kayser S, Moris A, Wallwiener D, Rammensee HG and Stevanovic S: A MAGE-A1 HLA-A A*0201 epitope identified by mass spectrometry. Cancer Res 61: 4072-4077, 2001.

15. Sahin U, Tureci O, Schmitt H, Cochlovius B, Johannes T, Schmits R, Stenner F, Luo G, Schobert I and Pfreundschuh M: Human neoplasms elicit multiple specific immune responses in the autologous host. Proc Natl Acad Sci USA 92: 11810-11813, 1995.

16. Gure AO, Stockert E, Scanlan MJ, Keresztes RS, Jager D, Altorki NK, Old LJ and Chen YT: Serological identification of embryonic neural proteins as highly immunogenic tumor antigens in small cell lung cancer. Proc Natl Acad Sci USA 97: 4198-4203, 2000.

17. Scanlan MJ, Gure AO, Jungbluth AA, Old LJ and Chen YT: Cancer/testis antigens: an expanding family of targets for cancer immunotherapy. Immunol Rev 188: 22-32, 2002.

18. Caballero OL and Chen YT: Cancer/testis (CT) antigens: potential targets for immunotherapy. Cancer Sci 100: 2014-2021, 2009.

19. Simpson AJ, Caballero OL, Jungbluth A, Chen YT and Old LJ: Cancer/testis antigens, gametogenesis and cancer. Nat Rev Cancer 5: 615-625, 2005.

20. Kim YD, Park HR, Song MH, Shin DH, Lee CH, Lee MK and Lee SY: Pattern of cancer/testis antigen expression in lung cancer patients. Int J Mol Med 29: 656-662, 2012.

21. Chen YT, Gure AO, Tsang S, Stockert E, Jager E, Knuth A and Old LJ: Identification of multiple cancer/testis antigens by allogeneic antibody screening of a melanoma cell line library. Proc Natl Acad Sci USA 95: 6919-6923, 1998.

22. Chen YT, Scanlan MJ, Sahin U, Tureci O, Gure AO, Tsang S, Williamson B, Stockert E, Pfreundschuh M and Old LJ: A testicular antigen aberrantly expressed in human cancers detected by autologous antibody screening. Proc Natl Acad Sci USA 94: 1914-1918, 1997.

23. Tureci O, Sahin U, Schobert I, Koslowski M, Scmitt H, Schild HJ, Stenner F, Seitz G, Rammensee HG and Pfreundschuh M: The SSX-2 gene, which is involved in the $t(X ; 18)$ translocation of synovial sarcomas, codes for the human tumor antigen HOM-MEL-40. Cancer Res 56: 4766-4772, 1996.

24. Tureci O, Sahin U, Zwick C, Koslowski M, Seitz G and Pfreundschuh M: Identification of a meiosis-specific protein as a member of the class of cancer/testis antigens. Proc Natl Acad Sci USA 95: 5211-5216, 1998.

25. Lee SY, Obata Y, Yoshida M, Stockert E, Williamson B, Jungbluth AA, Chen YT, Old LJ and Scanlan MJ: Immunomic analysis of human sarcoma. Proc Natl Acad Sci USA 100: 2651-2656, 2003

26. Lee SY, Williamson B, Caballero OL, Chen YT, Scanlan MJ, Ritter G, Jongeneel CV, Simpson AJ and Old LJ: Identification of the gonad-specific anion transporter SLCO6A1 as a cancer/testis (CT) antigen expressed in human lung cancer. Cancer Immun 4: 13, 2004.

27. Song MH, Ha JC, Lee SM, Park YM and Lee SY: Identification of BCP-20 (FBXO39) as a cancer/testis antigen from colon cancer patients by SEREX. Biochem Biophys Res Commun 408: 195-201, 2011.

28. Hasegawa K, Ono T, Matsushita H, Shimono M, Noguchi Y, Mizutani Y, Kodama J, Kudo T and Nakayama E: A-kinase anchoring protein 3 messenger RNA expression in ovarian cancer and its implication on prognosis. Int J Cancer 108: 86-90, 2004. 
29. Zendman AJ, Cornelissen IM, Weidle UH, Ruiter DJ and van Muijen GN: CTp11, a novel member of the family of human cancer/testis antigens. Cancer Res 59: 6223-6229, 1999.

30. Conklin D, Holderman S, Whitmore TE, Maurer M and Feldhaus AL: Molecular cloning, chromosome mapping and characterization of UBQLN3 a testis-specific gene that contains a ubiquitin-like domain. Gene 249: 91-98, 2000.

31. Zhao L, Mou DC, Peng JR, Huang L, Wu ZA and Leng XS Diagnostic value of cancer-testis antigen $\mathrm{mRNA}$ in peripheral blood from hepatocellular carcinoma patients. World J Gastroenterol 16 : 4072-4078, 2010.

32. Vijayaraghavan S, Liberty GA, Mohan J, Winfrey VP, Olson GE and Carr DW: Isolation and molecular characterization of AKAP110, a novel, sperm-specific protein kinase A-anchoring protein. Mol Endocrinol 13: 705-717, 1999.
33. Carnegie GK, Means CK and Scott JD: A-kinase anchoring proteins: from protein complexes to physiology and disease. IUBMB Life 61: 394-406, 2009.

34. Sharma S, Qian F, Keitz B, Driscoll D, Scanlan MJ, Skipper J, Rodabaugh K, Lele S, Old LJ and Odunsi K: A-kinase anchoring protein 3 messenger RNA expression correlates with poor prognosis in epithelial ovarian cancer. Gynecol Oncol 99: 183-188, 2005. 